\title{
Xanthohumol attenuates tumour cell-mediated breaching of the lymphendothelial barrier and prevents intravasation and metastasis
}

\author{
Katharina Viola $\cdot$ Sabine Kopf - Lucie Rarova Kanokwan Jarukamjorn • \\ Nicole Kretschy • Mathias Teichmann · Caroline Vonach • Atanas G. Atanasov • \\ Benedikt Giessrigl $\cdot$ Nicole Huttary $\cdot$ Ingrid Raab $\cdot$ Sigurd Krieger • \\ Miroslav Strnad - Rainer de Martin • Philipp Saiko - Thomas Szekeres • \\ Siegfried Knasmüller • Verena M. Dirsch · Walter Jäger • Michael Grusch • \\ Helmut Dolznig • Wolfgang Mikulits $\cdot$ Georg Krupitza
}

Received: 10 September 2012/ Accepted: 25 February 2013/Published online: 17 March 2013

(C) Springer-Verlag Berlin Heidelberg 2013

\begin{abstract}
Health beneficial effects of xanthohumol have been reported, and basic research provided evidence for anti-cancer effects. Furthermore, xanthohumol was shown to inhibit the migration of endothelial cells. Therefore, this study investigated the anti-metastatic potential of xanthohumol. MCF-7 breast cancer spheroids which are placed on lymphendothelial cells (LECs) induce "circular chemorepellent-induced defects" (CCIDs) in the LEC monolayer resembling gates for intravasating tumour bulks at an early step of lymph node colonisation. NF- $\kappa B$ reporter-, EROD-, SELE-, 12(S)-HETE- and adhesion assays were performed to investigate the anti-metastatic properties of xanthohumol. Western blot analyses were used to elucidate
\end{abstract}

Katharina Viola and Sabine Kopf contributed equally to this work.

K. Viola $\cdot$ S. Kopf $\cdot$ N. Kretschy $\cdot$ M. Teichmann .

C. Vonach · B. Giessrigl - N. Huttary · I. Raab ·

S. Krieger · G. Krupitza $(\bowtie)$

Institute of Clinical Pathology, Medical University of Vienna,

Waehringer Guertel 18-20, 1090 Vienna, Austria

e-mail: georg.krupitza@meduniwien.ac.at

L. Rarova $\cdot$ M. Strnad

Centre of the Region Haná for Biotechnological and Agricultural Research, Faculty of Science, Palacký University, Šlechtitelů 11, 78371 Olomouc, Czech Republic

K. Jarukamjorn · W. Jäger

Department for Clinical Pharmacy and Diagnostics,

Faculty of Life Sciences, University of Vienna,

Althanstrasse 14, 1090 Vienna, Austria

\section{K. Jarukamjorn}

Department of Pharmaceutical Chemistry,

Faculty of Pharmaceutical Sciences, Khon Kaen University,

Khon Kaen 40002, Thailand the mechanisms inhibiting CCID formation. Xanthohumol inhibited the activity of CYP, SELE and NF-kB and consequently, the formation of CCIDs at low micromolar concentrations. More specifically, xanthohumol affected ICAM-1 expression and adherence of MCF-7 cells to LECs, which is a prerequisite for CCID formation. Furthermore, markers of epithelial-to-mesenchymal transition (EMT) and of cell mobility such as paxillin, MCL2 and S100A4 were suppressed by xanthohumol. Xanthohumol attenuated tumour cell-mediated defects at the lymphendothelial barrier and inhibited EMT-like effects thereby providing a mechanistic explanation for the anti-intravasative/anti-metastatic properties of xanthohumol. 
Keywords Xanthohumol · Cancer intravasation · Lymph endothelium · Adhesion · Mobility

$\begin{array}{ll}\text { Abbreviations } \\ \text { ALOX } & \text { Lipoxygenase A } \\ \text { CCIDs } & \text { Circular chemorepellent-induced defects } \\ \text { CYP } & \text { Cytochrome P450 } \\ \text { EMT } & \text { Epithelial-to-mesenchymal transition } \\ \text { EROD } & \text { Ethoxyresorufin- } O \text {-deethylase } \\ \text { HUVEC } & \text { Human umbilical vein endothelial cell } \\ \text { ICAM-1 } & \text { Intercellular adhesion molecule 1 } \\ \text { LEC } & \text { Lymphendothelial cell } \\ \text { MCL2 } & \text { Myosin light chain 2 } \\ \text { SELE } & \text { Selectin E } \\ \text { 12(S)-HETE } & 12(S) \text { Hydroxyeicosatetraenoic acid }\end{array}$

\section{Introduction}

A number of health beneficial effects are ascribed to the prenylated flavonoid xanthohumol (2,4',4-trihydroxy- $6^{\prime}$ methoxy 3 'prenylchalcone) which is the main constituent of hop cones (Humulus lupulus L.) (Magalhães et al. 2009). Therefore, xanthohumol is also present in beer, hop cone tea (Stevens and Page 2004; Stevens et al. 1999), and more concentrated also in enriched beverage formulations (Wunderlich et al. 2005). Xanthohumol possesses antiproliferative activity in several cancer cell lines such as human breast cancer MCF-7, colon cancer HT-29 and ovarian cancer A-2780 cells (Miranda et al. 1999) and significantly induces apoptosis in HCT116 colon cancer cells by down-regulating Bcl-2 and activating the caspase cascade (Pan et al. 2005). Furthermore, xanthohumol was shown to repress NF-kB activation in benign and malignant BHP-1 and PC3 prostate epithelial cells (Colgate et al. 2007). Recently, it was demonstrated that ductal breast cancer cells, which spread through the lymphatic vasculature, force lymphendothelial cells (LECs) to give way to tumour bulks thereby enabling the intravasation of cancer cells into the vasculature. Hence, the migration of LECs is a hallmark event for breast cancer metastasis and therefore, a target for the prevention and therapeutic intervention with regard to tumour spreading. An assay was developed which resembles the intravasation of tumour emboli through the lymphovascular barrier. This assay measures the size of circular chemorepellent-induced defects (CCIDs) in the LEC monolayer that are generated by 12(S)-HETEsecreting cancer spherules and that will not be repaired over time (Uchide et al. 2007; Kerjaschki et al. 2011). 12(S)-HETE, also known as "endothelial retraction factor" (Honn et al. 1994), repels LECs thereby forming large cellfree areas through which cancer emboli can trespass
(Madlener et al. 2010). The CCID assay was validated in a breast cancer xenograft mouse model and significantly correlates with the data obtained from paired samples of patients with ductal breast cancer comparing the presence of 12(S)-HETE in the primary tumour versus the lymph node metastasis (Kerjaschki et al. 2011). In this study, we investigated how xanthohumol inhibited CCID formation induced by breast cancer cell spheroids.

\section{Materials and methods}

Chemicals

The I- $\kappa \mathrm{B} \alpha$ phosphorylation inhibitor (E)-3-[(4-methylphenylsulfonyl]-2-propenenitrile (Bay11-7082) and baicalein (EI-106) were purchased from Biomol (Hamburg, Germany), 12(S)-HETE from Cayman Chemical (Ann Arbor, MI, USA), Wogonin from Calbiochem (Darmstadt, Germany), xanthohumol (2,4',4-trihydroxy-6'-methoxy3'prenylchalcone) from Naturalchemics (Homburg, Germany) and SKF-525A (2-diethylaminoethyl 2,2-diphenylpentanoate was transferred to 24-well plates containing LEC monolayers proadifen) from Sigma-Aldrich (Munich, Germany). Mouse monoclonal anti-CD54 (ICAM-1) antibody was from Immunotech (Marseille, France) and polyclonal rabbit anti-paxillin (H-114) (SC-5574) was from Santa Cruz Biotechnology (Heidelberg, Germany). Monoclonal mouse anti-phospho-p44/42 MAPK (Erk1/2) (Thr202/Tyr204) (E10), monoclonal rabbit anti-p44/42 MAPK (Erk1/2) (137F5), polyclonal rabbit anti-phospho-Myosin Light Chain 2 (Ser19), polyclonal rabbit anti-Myosin Light Chain 2 , and polyclonal rabbit anti-MYPT1 were from Cell Signaling (Danvers, MA, USA). Monoclonal mouse anti$\beta$-actin (clone AC-15) and polyclonal rabbit anti-S100A4 were from Sigma-Aldrich (Munich, Germany), and polyclonal rabbit anti-phospho-MYPT1 (Thr696) was from Upstate (Lake Placid, NY, USA). Monoclonal mouse antiCD31 (JC70A), polyclonal rabbit anti-mouse and anti-rabbit IgGs were from Dako (Glostrup, Denmark).

\section{Cell culture}

Human MCF-7 and MDA-MB231 breast cancer cells were purchased from the American Type Culture Collection (ATCC, Rockville, MD, USA) and grown in MEM medium supplemented with $10 \%$ foetal calf serum (FCS), $1 \%$ penicillin/streptomycin (PS) (Invitrogen, Karlsruhe, Germany). Telomerase-immortalised human lymphendothelial cells (LECs) were grown in EGM2 MV (Clonetics CC4147, Allendale, NJ, USA), all at $37{ }^{\circ} \mathrm{C}$ in a humidified atmosphere containing $5 \% \mathrm{CO}_{2}$. For CCID formation assays, LECs were stained with cytotracker green 
purchased from Invitrogen (Karlsruhe, Germany). Human umbilical vein endothelial cells (HUVEC) were isolated and cultured in M199 medium supplemented with $20 \%$ FCS, antibiotics, endothelial cell growth supplement and heparin as previously described (Zhang et al. 1998).

\section{3-D co-cultivation of breast cancer spheroids with LEC monolayers}

MCF-7 cells were transferred to $30 \mathrm{ml}$ MEM medium containing $6 \mathrm{ml}$ of $1.6 \%$ methylcellulose solution $(0.3 \%$ final concentration; Cat. No.: M-512, 4000 centipoises; Sigma-Aldrich, Munich, Germany). $150 \mu \mathrm{l}$ of this cell suspension was transferred to each well of a 96-well plate (Greiner Bio-one, Cellstar 650185, Kremsmünster, Austria) to allow spheroid formation within $48 \mathrm{~h}$. Then, MCF-7 spheroids were washed in PBS and transferred to cytotracker-stained LEC monolayers that were seeded in 24-well plates (Costar 3524, Sigma-Aldrich, Munich, Germany) in $2 \mathrm{ml}$ EGM2 MV medium.

During the experiments, which were mostly short term, we did not observe toxic effects of xanthohumol (monitored by HOPI staining; Grusch et al. 2002).

\section{CCID assay}

In this model, the sizes of the cell-free areas (circular chemorepellent-induced defects; CCIDs) are measured, which are formed in the endothelial monolayer directly underneath the tumour spheroids (Giessrigl et al. 2012; Vonach et al. 2011; Kerjaschki et al. 2011; Madlener et al. 2010). MCF-7 cell spheroids (3,000 cells/spheroid) were transferred to 24-well plates containing LEC monolayers. After $4 \mathrm{~h}$ of incubation, the CCID areas in the LEC monolayers underneath the MCF-7 spheroids were photographed using an Axiovert (Zeiss, Jena, Germany) fluorescence microscope to visualise cytotracker(green)stained LECs underneath the spheroids. CCID areas were calculated with the Axiovision Re. 4.5 software (Zeiss, Jena, Germany). MCF-7 spheroids were treated with the indicated compounds or solvent (DMSO) as negative control. Each experiment was performed in triplicate, and for each condition, the CCID size of 12 or more spheroids (unless otherwise specified) was measured.

\section{SDS gel electrophoresis and Western blotting}

LECs were grown in petri dishes $(6 \mathrm{~cm}$ diameter) to $8 \%$ confluence and treated with $1 \mu \mathrm{M} 12(S)$-HETE and/or $25 \mu \mathrm{M}$ xanthohumol. Then, cells were washed twice with cold PBS and lysed in a buffer containing $150 \mathrm{mM} \mathrm{NaCl}$,
$50 \mathrm{mM}$ Tris $\mathrm{pH} 8.0,1 \%$ Triton-X-100, $1 \mathrm{mM}$ phenylmethylsulfonyl fluoride (PMSF) and $1 \mathrm{mM}$ Protease Inhibitor Cocktail (PIC) (Sigma, Schnelldorf, Germany). The lysate was centrifuged at $12,000 \mathrm{rpm}$ for $20 \mathrm{~min}$ at $4{ }^{\circ} \mathrm{C}$. Supernatant was transferred into a $1.5-\mathrm{ml}$ tube and stored at $-20{ }^{\circ} \mathrm{C}$ until further analysis. Equal amounts of protein lysate were mixed with SDS (sodium dodecyl sulphate) sample buffer and loaded onto a $10 \%$ polyacrylamide gel. SDS polyacrylamide gel electrophoresis (PAGE) and Western blotting was according to the protocol described by Vonach et al. (2011).

\section{SELE (CD62E, E-selectin, ELAM)-induction assay}

Each well of a 96-well plate was coated with gelatine by applying $200 \mu \mathrm{l}$ of $1.0 \%$ gelatine for $10 \mathrm{~min}$ at room temperature. Outer wells (A1-A12, H1-H12, 1-H1 and A12-H12) contained only $200 \mu \mathrm{l} /$ well medium and served as an evaporation barrier. $1 \times 10^{4}$ HUVECs were seeded in each of the remaining wells in $200 \mu \mathrm{l}$ medium and grown for $48 \mathrm{~h}$ to optimal confluence. Increasing concentrations of xanthohumol were then added to the HUVECcontaining wells in triplicate, incubated for $30 \mathrm{~min}$, and then $10 \mathrm{ng} / \mathrm{ml} \mathrm{TNF} \alpha$ was added per well to stimulate NF$\kappa \mathrm{B}$, and thus SELE. After further $4 \mathrm{~h}$ incubation, the levels of SELE in each of the HUVEC-containing wells were determined by enzyme-linked activity assays (ELISAs) as described below.

\section{Cell-surface ELISA SELE}

Cells were washed once with PBS and fixed with $0.1 \%$ glutaraldehyde (Sigma-Aldrich, Munich, Germany) for $15 \mathrm{~min}$ at room temperature. Then, cells were washed $3 \times$ with $200 \mu \mathrm{l}$ per well PBS/0.05 \% Tween 20, blocked with $200 \mu \mathrm{l} /$ well $5 \% \mathrm{BSA} / \mathrm{PBS}$ for $1 \mathrm{~h}$, and washed again $3 \times$ with $200 \mu \mathrm{l}$ per well PBS/0.05\% Tween 20. Then, antiSELE-antibody (clone BBA-1, R\&D Systems, Minneapolis, MN, USA) diluted 1:5,000 in 0.1\% BSA/PBS (100 $\mu \mathrm{l}$ per well) was added for $1 \mathrm{~h}$ at room temperature and washed thereafter $5 \times$ with $200 \mu \mathrm{l}$ per well PBS/0.05\% Tween 20. Subsequently, goat anti-mouse-HRP antibody (Sigma-Aldrich, Munich, Germany) diluted 1:10,000 in $0.1 \%$ BSA/PBS (100 $\mu \mathrm{l}$ per well) was applied, and the cells were incubated for $1 \mathrm{~h}$ in the dark at room temperature. After decanting, cells were washed $5 \times$ with $200 \mu \mathrm{l}$ per well PBS/0.05\% Tween 20. The HRP-activity of the cells in each well was estimated using the Fast-OPD (o-phenylenediamine dihydrochloride) (Sigma-Aldrich, Munich, Germany) assay as described (Gridling et al. 2009), and absorbance was measured at $\mathrm{OD}_{492 \mathrm{~nm}}$ in a vertical spectrophotometer. 


\section{Cytotoxicity testing}

For the SELE expression assay, the toxicity of xanthohumol was assessed in HUVECs by Calcein AM cytotoxicity assays in 96-well microtitre plates (Madlener et al. 2009). Twenty microlitre portions of each of the xanthohumol concentrations were added in triplicate to the cells, which were then incubated at $37{ }^{\circ} \mathrm{C}$ in an atmosphere containing $5 \% \mathrm{CO}_{2}$ for $4 \mathrm{~h}$. Then, Calcein AM solution (Molecular Probes, Invitrogen, Karlsruhe, Germany) was added for $1 \mathrm{~h}$ according to the manufacturer's instructions. The fluorescence of viable cells was quantified using a Fluoroscan Ascent reader (Labsystems, Finland), and on the basis of triplicate experiments, the cytotoxic concentrations were calculated.

\section{$\mathrm{NF}-\kappa \mathrm{B}$ luciferase assay}

$10 \times 10^{6}$ HEK293-NF- $\kappa$ B-Luc cells (Panomics, Fremont, USA) were seeded in $20 \mathrm{ml}$ full growth DMEM medium in a $15-\mathrm{cm}$ dish. Next day, cells were transfected with an expression plasmid for green fluorescence protein (pEGFPN1; Clontech, CA, USA). A total of $30 \mu \mathrm{l} \mathrm{Lipofectamin}$ 2000 (Invitrogen, Karlsruhe, Germany) and $7.5 \mu \mathrm{g}$ DNA were mixed in $2 \mathrm{ml}$ transfection medium and incubated for $20 \mathrm{~min}$ at room temperature and then added to the cells. After incubation for $6 \mathrm{~h}$ in humidified atmosphere containing $5 \% \mathrm{CO}_{2}, 4 \times 10^{4}$ cells per well were seeded in serum- and phenol red-free DMEM in a transparent 96-well plate. On the next day, cells were treated with 5, 10 and $25 \mu \mathrm{M}$ xanthohumol and $10 \mu \mathrm{M}$ Bay11-7082 as a specific inhibitor of $\mathrm{NF}-\kappa \mathrm{B}$ (control). One hour after treatment, cells were stimulated with $2 \mathrm{ng} / \mathrm{ml}$ human recombinant $\mathrm{TNF} \alpha$ for additional $4 \mathrm{~h}$. Luminescence of the firefly luciferase and fluorescence of the GFP were quantified on a GeniusPro plate reader (Tecan, Grödig, Austria). The luciferase signal derived from the $\mathrm{NF}-\kappa \mathrm{B}$ reporter was normalised by the GFP-derived fluorescence to account for differences in cell number or transfection efficiency (Giessrigl et al. 2012).

Ethoxyresorufin- $O$-deethylase (EROD) assay selective for CYP1A1 activity

MDA-MB-231 and MCF-7 breast cancer cells were grown in phenol red-free RPMI 1640 tissue culture medium (PAN Biotech, Aldenbach, Germany), supplemented with $10 \%$ FCS and $1 \%$ PS (Invitrogen, Karlsruhe, Germany) under standard conditions at $37^{\circ} \mathrm{C}$ in a humidified atmosphere containing $5 \% \mathrm{CO}_{2}$. Twenty-four hours before treatment, the cells were transferred to RPMI 1640 medium (Invitrogen, Karlsruhe, Germany) supplemented with $2.5 \%$ charcoal-stripped FCS (PAN Biotech, Aldenbach, Germany) and $1 \% \mathrm{P} / \mathrm{S}$. Test compounds were dissolved in DMSO and diluted with medium (final DMSO concentration $<0.1 \%$ ). Experiments were carried out in triplicate. Blanks contained DMSO in the medium of the test compounds. After $18 \mathrm{~h}$ of incubation, ethoxyresorufin (final concentration $5.0 \mu \mathrm{M}$, Sigma-Aldrich, Munich, Germany) was added and $0.4 \mathrm{ml}$ aliquots of the medium were sampled after $200 \mathrm{~min}$. Subsequently, the formation of resorufin was analysed by spectrofluorometry (PerkinElmer LS50B, Waltham, MA, USA) with an excitation wavelength of $530 \mathrm{~nm}$ and an emission wavelength of $585 \mathrm{~nm}$.

\section{Adhesion assay}

MCF-7 cells (15,000 cells/well) were seeded in serum-free medium (DMEM containing $0.5 \% \mathrm{BSA}, 2 \mathrm{mM} \mathrm{CaCl}_{2}$ and $\left.2 \mathrm{mM} \mathrm{MgCl}_{2}\right)$. Then, $500 \times$ CytoTracker $^{\mathrm{TM}}(500 \times$ CytoTracker $^{\mathrm{TM}}$ Solution from CytoSelect ${ }^{\mathrm{TM}}$ Tumor-endothelium Adhesion Assay from Cell Biolabs, Inc., San Diego, CA, USA, CBA-215) was added to the cell suspension ( $2 \mu$ l CytoTracker ${ }^{\mathrm{TM}}$ to $1 \mathrm{ml}$ suspension), incubated for $1 \mathrm{~h}$ at $37^{\circ} \mathrm{C}$ and centrifuged at 1,000 rpm for $2 \mathrm{~min}$. Then, the medium was aspirated, the cell pellet was washed $3 \times$ with serum-free medium (DMEM containing $0.5 \%$ BSA, $2 \mathrm{mM} \mathrm{CaCl}_{2}$ and $2 \mathrm{mM} \mathrm{MgCl}_{2}$ ), and then, the cell pellet was re-suspended in EGM2 MV medium. Meanwhile, the medium was aspirated from endothelial cell culture (in wells of a 48 well plate), collected in Eppendorf tubes, and either Bay11-7082 (15 $\mu \mathrm{M})$, xanthohumol or DMSO (Sigma-Aldrich, Munich, Germany) was added. Then, the medium was re-distributed to LEC layers and incubated for $10 \mathrm{~min}$. Also the MCF-7 cell suspension, which was stained with CytoTracker ${ }^{\mathrm{TM}}$, was treated with Bay11-7082, xanthohumol or DMSO and incubated for $10 \mathrm{~min}$ at room temperature. Furthermore, the medium was aspirated from the 48 -well plate, and $200 \mu \mathrm{l}$ of treated MCF-7 cell suspension was added to each well containing LECs grown in monolayers and incubated for $40 \mathrm{~min}$ at $37{ }^{\circ} \mathrm{C}$. Then, the medium was aspirated from each well and washed $3 \times$ with $250 \mu 1 \times$ Wash Buffer $(10 \times$ Wash Buffer was from CytoSelect ${ }^{\mathrm{TM}}$ Tumor-endothelium Adhesion Assay). Before the third wash, cells were inspected for morphological changes under the microscope. Then, the final wash was aspirated, and the plate was tapped on a flint-free paper towel. $150 \mu \mathrm{l}$ of $1 \times$ Lysis Buffer $\left(4 \times\right.$ Lysis Buffer were from CytoSelect ${ }^{\mathrm{TM}}$ Tumorendothelium Adhesion Assay) was added to each well and lysed by the shearing forces through a pipette tip. $100 \mu \mathrm{l}$ of the lysate was transferred to a 96-well clear bottom plate, and then, the fluorescence was read with a fluorescence plate reader at $485 / 530 \mathrm{~nm}$. 


\section{2(S)-HETE assay}

\section{Cell culture}

ALOX15 of MCF-7 $7^{\text {VEGF-C }}$ cells was knocked down by lentiviral-packaged shRNA, and 12(S)-HETE synthesis was reconstituted by stable transfection of ALOX12 cDNA as described resulting in MCF-7 $7^{\text {VEGF-C/80/1/2ALOX15- }}$ pTAGALOX12-V5 cells (Kerjaschki et al. 2011). MCF-7 VEGF-C/ 80/1/2ALOX15- pTAG-ALOX12-V5 cells were cultivated in MEM medium (Gibco \#10370-047) supplemented with $10 \%$ FCS (foetal calf serum), $1 \%$ GlutaMAX $^{\mathrm{TM}}-\mathrm{I}$ (Gibco \#35050-038), $1 \%$ penicillin/streptomycin (Gibco \#15140148), $1 \mathrm{mg} / \mathrm{ml} \mathrm{G148-sulphate} \mathrm{(PAA,} \mathrm{\# P25-011),} 150 \mu \mathrm{g} /$ $\mathrm{ml}$ hygromycin B (Sigma-Aldrich, \#H3274) and $1 \mu \mathrm{g} / \mathrm{ml}$ puromycin. The cells were grown at $37{ }^{\circ} \mathrm{C}$ in a humidified atmosphere containing $5 \% \mathrm{CO}_{2}$.

\section{Treatment}

MCF-7 ${ }^{\text {VEGF-C/80/1/2ALOX15- }}$ pTAG-ALOX12-V5 cells were seeded in $3.5-\mathrm{cm}$ dishes and grown in $2.5 \mathrm{ml}$ complete MEM medium without selection pressure. The next day, the medium was changed for serum-free medium and cells were kept at $37{ }^{\circ} \mathrm{C}$ for $24 \mathrm{~h}$. Then, cells were treated with $10 \mu \mathrm{M}$ arachidonic acid (\#A3555, Sigma-Aldrich, St. Louis, MO 63103 USA) and simultaneously with different concentrations of the indicated compounds for $4 \mathrm{~h}$ when the supernatants were aspirated, centrifuged at $2000 \mathrm{rpm}$ at $4{ }^{\circ} \mathrm{C}$ for $5 \mathrm{~min}$, collected in cryotubes, flash frozen and stored at $-80{ }^{\circ} \mathrm{C}$ until analysis.

\section{2(S)-HETE extraction}

Medium samples of MCF-7 ${ }^{\text {VEGF-C/80/1/2ALOX15- }}$ TTAGALOX12-V5 cells were slowly thawed at room temperature and centrifuged at 3,000 rpm for $2 \mathrm{~min}$. Extraction cartridges (Oasis ${ }^{\mathrm{TM}}$ HLB $1 \mathrm{cc}$, Waters, Milford, MA) were equilibrated with $2 \times 1 \mathrm{ml}$ methanol (highest purity), $2 \times 1 \mathrm{ml}$ distilled $\mathrm{H}_{2} \mathrm{O}$ and $1.25 \mathrm{ml}$ of medium samples was passed through the cartridges. Afterwards, the cartridges were washed with $3 \times 1 \mathrm{ml}$ distilled $\mathrm{H}_{2} \mathrm{O}$ and 12(S)-HETE was eluted with $500 \mu \mathrm{l}$ methanol. The methanolic solution was flash frozen and stored at $-80{ }^{\circ} \mathrm{C}$ until further analysis.

\section{Analysis by 12(S)-HETE enzyme immunoassay (EIA)}

The 12(S)-HETE EIA kit (\#ADI-900-050) was purchased from Enzo Life Sciences (Lausen, Switzerland) and samples were prepared, and the assay performed according to the instructions of the manufacturer. In detail, the methanolic solution was evaporated with a speed-vac concentrator, $250 \mu \mathrm{l}$ of assay buffer was added to the dried samples and a 1:54 dilution was prepared. The standards (a

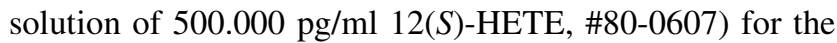
12(S)-HETE standard curve were prepared according to the instruction. Then, $100 \mu \mathrm{l}$ of the samples and standards were added to a 96-well plate coated with goat anti-rabbit IgG antibody (\#80-0060). Furthermore, $50 \mu$ of 12(S)-HETE conjugate (\#80-0610; blue solution) and $50 \mu \mathrm{l}$ of rabbit polyclonal antibody (\#80-0611; yellow solution) were added into the appropriate wells. Afterwards, the plate was incubated at room temperature for $2 \mathrm{~h}$ on a shaker (220 rpm). Then, wells were emptied, washed $3 \times$ with $400 \mu \mathrm{l}$ wash buffer (1:20 dilution of wash buffer concentrate, \#80-1286), and after the final wash, the plate was tapped on a flint-free paper towel in order to completely remove the wash buffer. $200 \mu \mathrm{l}$ of the pNpp substrate (\#800075) solution was pipetted into each well and incubated for $3 \mathrm{~h}$ at $37{ }^{\circ} \mathrm{C}$ in a humidified atmosphere containing $5 \%$ $\mathrm{CO}_{2}$. Then, $50 \mu \mathrm{l}$ of the stop solution (\#80-0247) was added into each well and absorbance was measured with a Wallac 1420 Victor 2 multilabel plate reader (PerkinElmer Life and Analytical Sciences).

\section{Statistical analysis}

For statistical analyses Excel 2003 software and Prism 5 software package (GraphPad, San Diego, CA, USA) were used. The values were expressed as mean \pm SEM, and the Student's $t$ test was applied to compare differences between control samples and treatment groups. Statistical significance level was set to $p<0.05$.

\section{Results}

Xanthohumol attenuates the formation of lymphendothelial defects

Placing MCF-7 tumour spheroids on LEC monolayers leads to rapid endothelial cell emigration from the spheroid zone generating endothelial cell-free areas (circular chemorepellent-induced defects; CCIDs) through which tumour cells can pass (Madlener et al. 2010). This resembles tumour intra-/extravasation and manifests an early step of metastasis. $100 \mu \mathrm{M}$ baicalein, an ALOX12/15 inhibitor, attenuated MCF-7 spheroid-induced CCID formation. CCIDs that were induced by MDA-MB231 spheroids were not inhibited (Fig. 1a, b), because MDA-MB231 cells do not express ALOX12 and ALOX15 (in contrast to MCF-7 cells, which do express ALOX15; Kerjaschki et al. 2011). Notably, inhibiting NF- $\kappa \mathrm{B}$ activation with $10 \mu \mathrm{M}$ Bay117082 attenuated CCID formation underneath MCF-7 and MDA-MB231 spheroids similarly. We showed that 

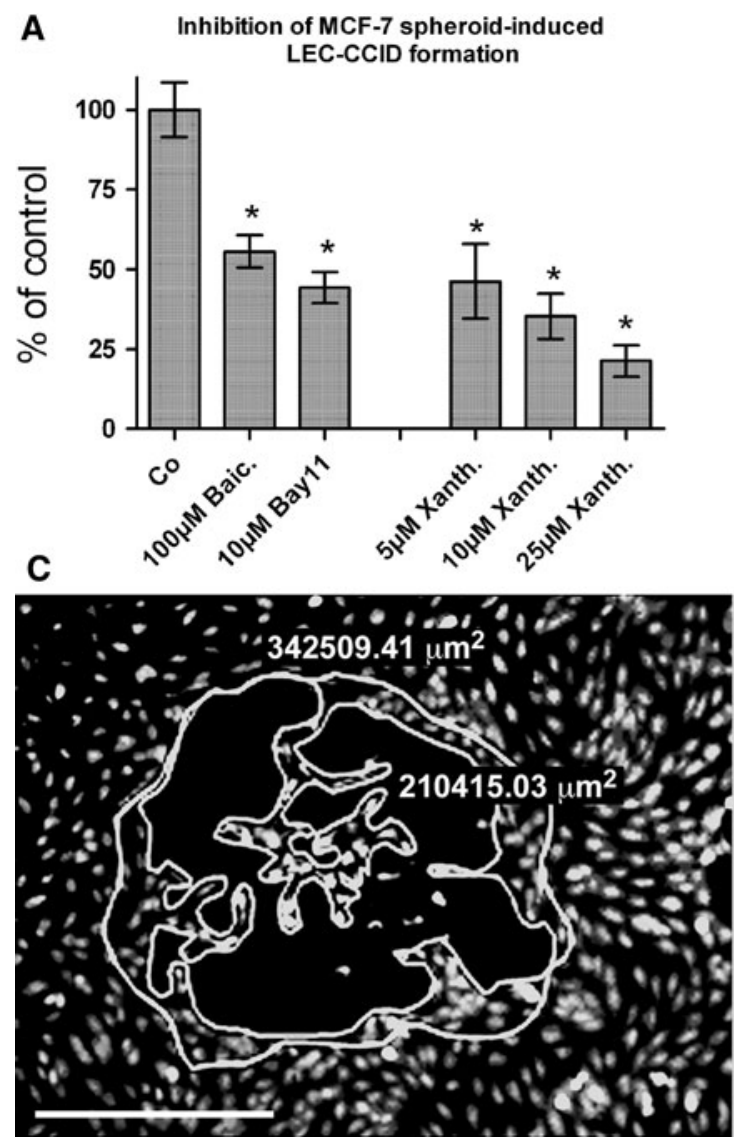

Fig. 1 Inhibition of CCIDs by xanthohumol. a MCF-7 spheroids and b MDA-MB231 spheroids were placed on LEC monolayers and cocultivated either with solvent (DMSO; Co) or with the indicated concentrations of xanthohumol, or $100 \mu \mathrm{M}$ baicalein, or $10 \mu \mathrm{M}$ Bay11-7082 for $4 \mathrm{~h}$, and then, the areas of CCIDs were measured using a Zeiss Axiovert microscope and Axiovision software. Error bars indicate SEM, asterisks indicate significance compared to

baicalein and Bay11-7082 inhibited MCF-7-triggered CCIDs additively (Viola et al. 2012). Therefore, NF- $\kappa B$ (Vonach et al. 2011) and ALOX15 (Kerjaschki et al. 2011) contributed to the formation of MCF-7-triggered CIDDs independently.

Xanthohumol was reported to inhibit NF- $\mathrm{KB}$ (Colgate et al. 2007), and hence, xanthohumol was tested regarding its potential to inhibit CCID formation in LEC monolayers induced by MCF-7 and MDA-MB231 spheroids. Underneath MCF-7 spheroids low micromolar concentrations of xanthohumol (IC50 $=\sim 5 \mu \mathrm{M}$ ) attenuated CCID formation (Fig. 1a, c), whereas the $\sim 20$-fold concentration of xanthohumol was required to achieve similar attenuation underneath MDA-MB231 spheroids (IC50 $=\sim 100 \mu \mathrm{M}$; Fig. 1b). This could have been either due to an efficient exclusion of xanthohumol from MDA-MB231 cells or due to a minor inhibitory effect of xanthohumol on NF- $\kappa B$.
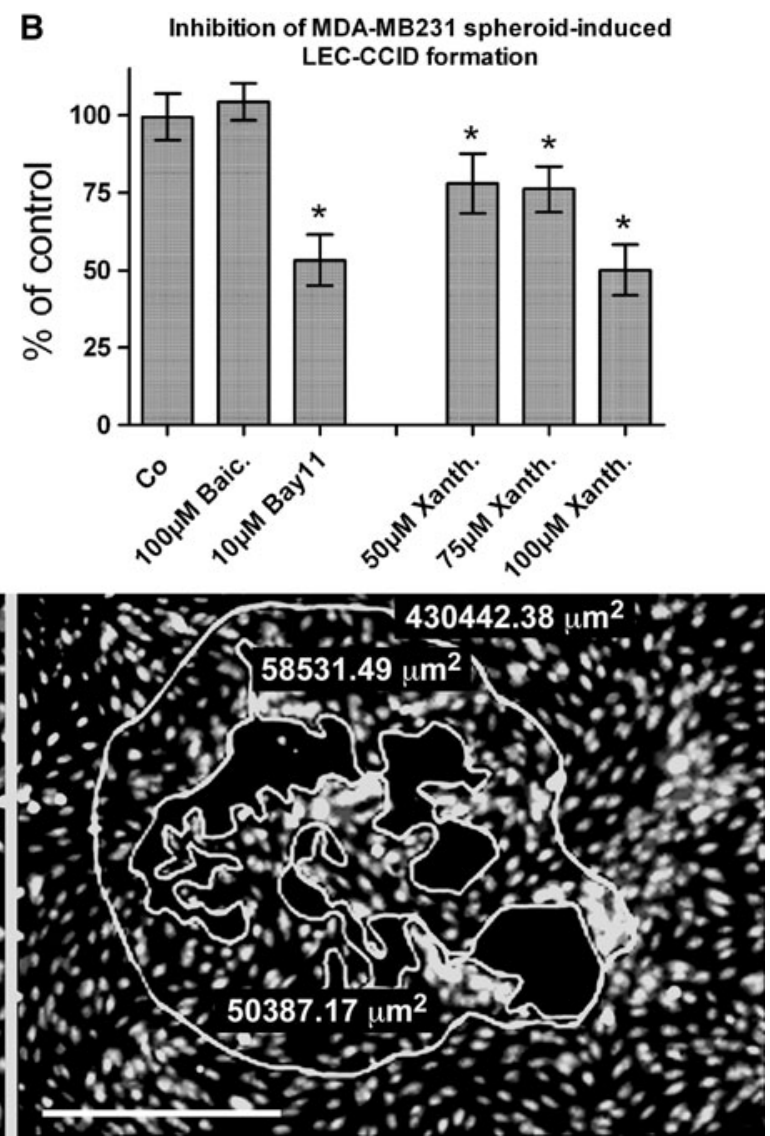

control $(p<0.05)$. c MCF-7 spheroids were placed on LEC monolayers and co-cultivated either with solvent (DMSO; Co) or with $10 \mu \mathrm{M}$ xanthohumol for $4 \mathrm{~h}$ and then the areas of CCIDs were photographed. Left panel microscopic power field of a CCID underneath a MCF-7 spheroid of an untreated co-culture and right side of a co-culture treated with $25 \mu \mathrm{M}$ xanthohumol. Scale bars $700 \mu \mathrm{m}$

Xanthohumol inhibits NF- $\kappa \mathrm{B}$ activity and selectin E expression

To elucidate to which extent xanthohumol inhibits NF- $\mathrm{BB}$ activity, we used a respective reporter gene assay (Giessrigl et al. 2012). $5 \mu \mathrm{M}$ and $10 \mu \mathrm{M}$ xanthohumol inhibited $\mathrm{TNF} \alpha$-induced and NF- $\mathrm{KB}$-mediated luciferase reporter gene expression (Fig. 2) by only 15-25\% (respectively), yet it attenuated CCIDs by 50-65\% (respectively). $25 \mu \mathrm{M}$ xanthohumol inhibited luciferase reporter activation by $\sim 65 \%$ (in HEK293 cells) and CCID formation by $\sim 75 \%$ (in MCF-7 cells). This was in accordance with recent findings (Colgate et al. 2007). Our date suggested that xanthohumol inhibits CCID formation through two distinct pathways: one dependent of NF- $\mathrm{KB}$ (at high concentrations) and the other independent of NF- $\mathrm{KB}$ (at low concentrations). Furthermore, the results indicated that 


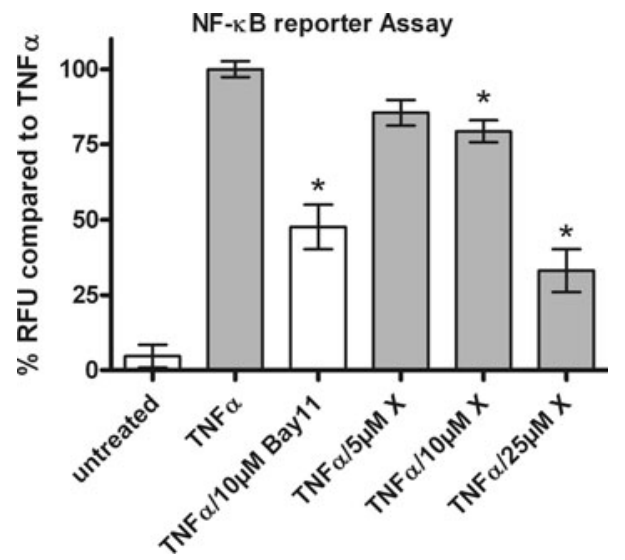

Fig. 2 Effect of xanthohumol on the NF- $\kappa \mathrm{B}$ transactivation activity. $10 \times 10^{6}$ HEK293-NFKB-Luc cells were transfected with the cDNA of green fluorescence protein (GFP). After incubation for $6 \mathrm{~h}$, $4 \times 10^{4}$ cells per well were seeded in serum- and phenol red-free DMEM in a 96 transparent well plate. On the next day, cells were treated with indicated concentrations xanthohumol (X), $10 \mu \mathrm{M}$ Bay11-7082 (Bay11) as a specific inhibitor of NF- $\mathrm{KB}$, or solvent (DMSO; untreated). One hour after treatment, cells were stimulated with $2 \mathrm{ng} / \mathrm{ml}$ human recombinant TNF $\alpha$ for additional $4 \mathrm{~h}$. Luminescence of the firefly luciferase and fluorescence of the GFP were quantified on a GeniusPro plate reader. The luciferase signal derived from the NF- $\kappa \mathrm{B}$ reporter was normalised by the GFP-derived fluorescence to account for differences in cell number or transfection efficiency. Experiments were performed in triplicate. Asterisks indicate significance compared to untreated control $(p<0.05)$ and error bars indicate mean \pm SEM

MDA-MB321 cells are more resistant to the treatment with xanthohumol than MCF-7 cells. To further challenge the hypothesis that xanthohumol inhibits NF- $\mathrm{KB}$ in different cell lines with distinct efficiency, human umbilical vein endothelial cells (HUVECs) were pretreated with xanthohumol. Then, selectin E (SELE) expression was induced by $\mathrm{TNF} \alpha$, which is indicative for $\mathrm{NF}-\kappa \mathrm{B}$ activation (Table 1). The observed reduction in SELE expression upon treatment of HUVECs with increasing concentrations of xanthohumol was not significant suggesting that xanthohumol exerts its activity cell type-dependent. Nevertheless, there was evidence that the NF- $\kappa \mathrm{B}$ pathway was targeted by xanthohumol and that this is of relevance for the CCID-attenuating property of xanthohumol.

The NF- $\kappa$ B inhibitor Bay11-7082 and xanthohumol interfere with intercellular adhesion

Molecular adhesion of MCF-7 spheroids to LEC monolayers is a prerequisite of CCID formation (Viola et al. 2012). Lack of contact or mere physical contact of the spheroids to LECs by gravity is not sufficient to induce CCIDs. ICAM-1 is a prominent adhesion molecule establishing stable contact among different cell types. ICAM-1 is regulated by NF- $\mathrm{KB}$ (Holden et al. 2004; Collins et al. 1995) and expectedly, the NF- $\kappa B$ inhibitor Bay11-7082 inhibited ICAM-1 expression in LECs (Fig. 3a). In contrast, the expression of CD31, another intercellular adhesion protein, was unchanged upon treatment with Bay117082 (Viola et al. 2012). Also xanthohumol inhibited the expression of ÍCAM-1 and did not interfere with the expression of CD31 (Fig. 3b), which was consistent with its described property of an NF- $\kappa B$ inhibitor.

The down-regulation of ICAM-1 functionally correlated with a dose-dependent inhibition of adhesion of MCF-7 cells to LEC monolayers upon treatment with increasing concentrations of Bay11-7082 (Fig. 3a) or xanthohumol (Fig. 3b). It was recently demonstrated that knocking down ICAM-1 expression with specific siRNA reduced the adhesion of MCF-7 cells to LECs and attenuated the formation of CCIDs (Viola et al. 2012). Therefore, the inhibition of NF- $\kappa$ B by Bay11-7082 and by xanthohumol correlated with the inhibition of ICAM-1 and the adhesion of MCF-7 cells to LECs (Fig. 3c), which is mandatory for CCID formation.

Xanthohumol decreases CYP1A1 activity but induces 12(S)-HETE production

As concluded above, the inhibition of CCID formation by xanthohumol was not due to the inhibition of NF- $\kappa \mathrm{B}$ alone. In MCF-7 cells, the secretion of 12(S)-HETE, a metabolite

Table 1 Selectin E (SELE) expression in TNF $\alpha$-induced HUVECs

\begin{tabular}{|c|c|c|c|c|c|}
\hline Analysis & Control & $\mathrm{TNF} \alpha$ & $\mathrm{TNF} \alpha$ and $1 \mu \mathrm{M} \mathrm{X}$ & $\mathrm{TNF} \alpha$ and $10 \mu \mathrm{M} \mathrm{X}$ & $\mathrm{TNF} \alpha$ and $30 \mu \mathrm{M} \mathrm{X}$ \\
\hline \multicolumn{6}{|c|}{ Inflammatory reaction } \\
\hline SELE (OD) & $0.053(\mathrm{SD} 0.002)$ & $0.130(\mathrm{SD} 0.01)$ & 0.115 (SD 0.019) & 0.121 (SD 0.024) & $0.112(\mathrm{SD} 0.022)$ \\
\hline \multicolumn{6}{|l|}{ Cytotoxicity } \\
\hline CalceinAM (OD) & 46.4 (SD 2.7) & 44.5 (SD 6.4) & 44.6 (SD 3.9) & $43.8($ SD 5.3) & 38.5 (SD 8.0) \\
\hline
\end{tabular}

$1 \times 10^{4} \mathrm{HUVECs} /$ well were seeded in 96-well plates and grown to confluence. Indicated concentrations of xanthohumol (X) were added 30 min prior to application of $10 \mathrm{ng} / \mathrm{ml} \mathrm{TNF} \alpha$ for another $4 \mathrm{~h}$. Then, cells were fixed and SELE levels analysed by ELISA. In parallel, extracts were analysed by CalceinAM assay to monitor non-specific extract toxicity 

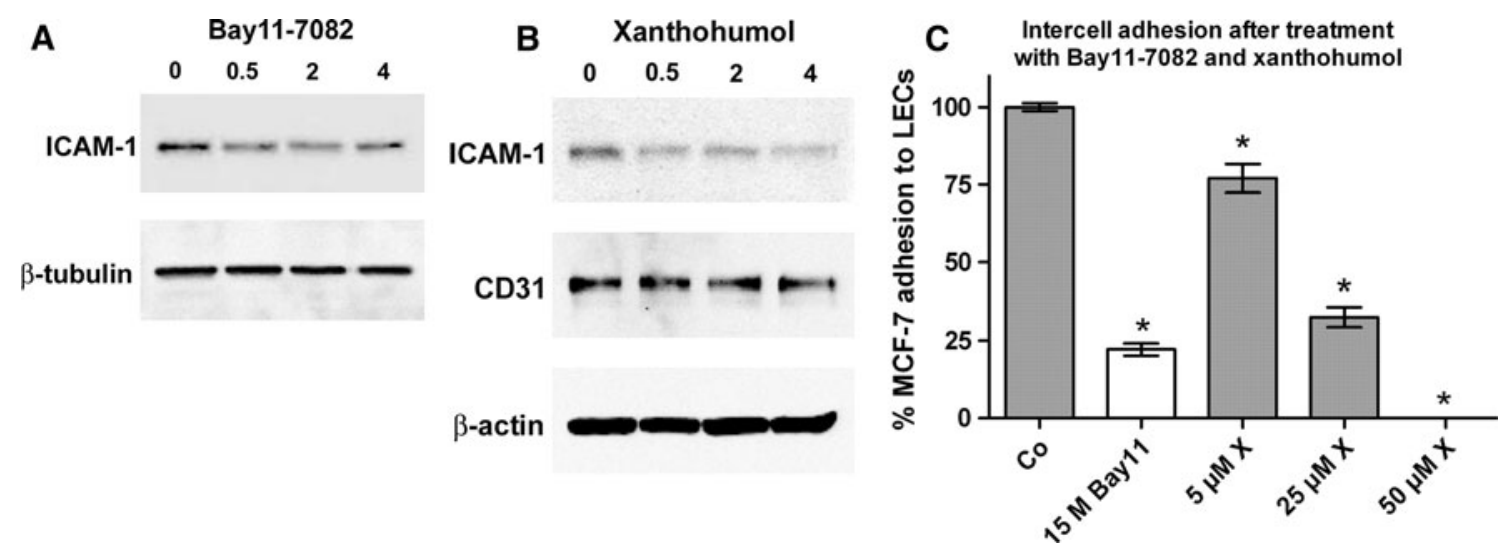

Fig. 3 Analysis of adherence protein expression. LECs were treated with a $10 \mu \mathrm{M}$ Bay11-7082, b $25 \mu \mathrm{M}$ xanthohumol for the indicated times. After cells were harvested, the protein lysates were analysed by Western blotting using the indicated antibodies. Solvent-treated LECs were used as negative control and $\beta$-actin analysis served as loading control. c Cell adhesion assay. Trypsinised and cytotracker-stained MCF-7 cells were placed on LEC monolayers that were pretreated with c $15 \mu \mathrm{M}$ Bay11-7082, and 5, 25 and $50 \mu \mathrm{M}$ xanthohumol. After $40 \mathrm{~min}$, cells were washed and the percentages of MCF-7 cells that adhered to LECs were determined by measuring the fluorescence at $485 / 530 \mathrm{~nm}$ in the mixed cell lysate. Experiments were performed in triplicate. Asterisks indicate significance compared to untreated control $(p<0.05)$ and error bars indicate mean \pm SEM of ALOX12/15, regulates CCID formation of LECs (Kerjaschki et al. 2011). Xanthohumol increased the 12(S)HETE production (Fig. 4a), whereas the specific NF- $\mathrm{KB}$ inhibitor Bay11-7082 did not. Therefore, ALOX12 was not inhibited by xanthohumol. However, xanthohumol inhibited the activity of CYP1A1, a member of the cytochrome P450 family, as determined by the ethoxyresorufin$O$-deethylase (EROD) catalytic assay (Fig. 4b). At higher concentration $(25 \mu \mathrm{M})$, xanthohumol inhibited CYP1A1 also in MDA-MB231 cells, yet less efficiently, and this was in accordance with the weak CCID inhibitory effect of xanthohumol in this cell line.

Also proadifen, which is a specific inhibitor of CYPs, attenuated CCID formation of LECs (Kretschy et al. 2013). ALOX12/15 and CYPs use arachidonic acid as their main substrate for the synthesis of their metabolites. Therefore, both enzymes are cross-talking, and the inhibition of one enzyme (i.e. CYP) provides more substrate for the respective other enzyme (ALOX12) resulting in increased metabolite levels [12(S)-HETE]. This phenomenon was also observed when CYP was inhibited by proadifen resulting in increased levels of the COX metabolite prostaglandin E2 (Kozak et al. 2000, COX also uses arachidonic acid as substrate). Consequently, the inhibition of CYP1A1 by xanthohumol or proadifen (Kretschy et al. 2013) prevents the consumption of arachidonic acid by CYP, and hence, higher substrate levels are available for ALOX12/15, which in turn produce more 12(S)-HETE as it was observed after treatment with xanthohumol (Fig. 4a). This implicated that the net effect of xanthohumol regarding the inhibition of CCID formation prevailed over the CCID-promoting induction of 12(S)-HETE synthesis.
Also other arachidonic acid metabolising enzymes, COX1/ 2 , become inhibited by xanthohumol (Gerhäuser et al. 2002). However, this very property of xanthohumol is unlikely to contribute to the inhibition of CCID formation, because this phenomenon is independent of COX1/2 (Kerjaschki et al. 2011; Madlener et al. 2010).

Xanthohumol inhibits paxillin and MLC2 in LECs

Since LECs migrate underneath MCF-7 spheroids (Kerjaschki et al. 2011), the expression of mobility proteins was analysed in activated LECs in response to xanthohumol. LECs were directly treated with 12(S)-HETE (mimicking the effect of a MCF-7 spheroid) to study the interfering effect of xanthohumol on cell motility-related protein expression. Xanthohumol treatment dephosphorylated (inactivated) MLC2 and downregulated the expression of the EMT markers S100A4 and paxillin, and it reversed 12(S)-HETE-modulated suppression of Erk1/2 phosphorylation (Fig. 5). Therefore, xanthohumol has the potential to affect rapid and directional LEC migration (Deakin and Turner 2008), which is a prerequisite of CCID formation (Kerjaschki et al. 2011).

\section{Discussion}

In search of new anti-neoplastic drugs, natural products like xanthohumol are of particular interest, because of their availability, tolerability and multi-target properties that may synergize to achieve the anticipated effects. Although contained in beer, to achieve effective concentrations in the 


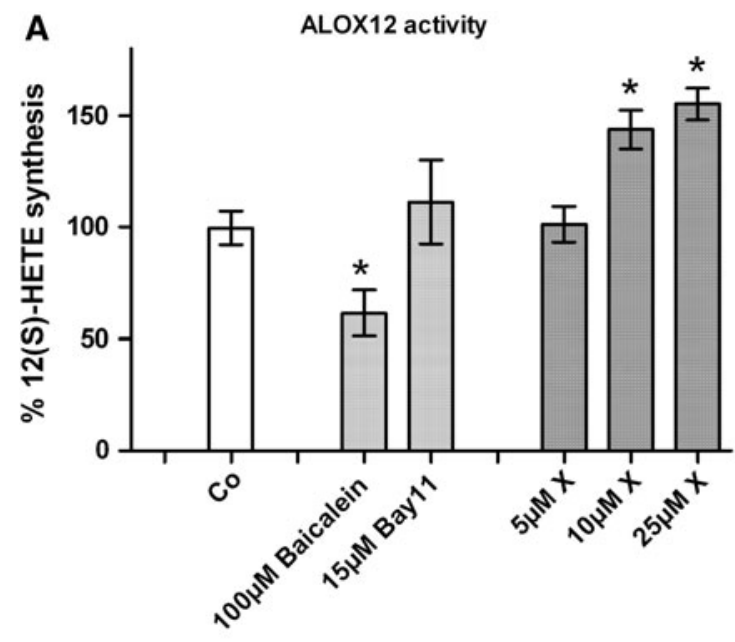

Fig. 4 Influence on 12(S)-HETE synthesis by ALOX12 a MCF$7^{\text {VEGF-C/80/1/2ALOX15- }}$ TAAG-ALOX12-V5 cells (MCF-7 ${ }^{\text {ALOX12 }}$ ) were seeded in $3.5-\mathrm{cm}$ dishes and grown to $70 \%$ confluence and treated with $10 \mu \mathrm{M}$ arachidonic acid together with the indicated compounds (baicalein, Bay11-7082, xanthohumol), DMSO was used as control (Co) for $4 \mathrm{~h}$. Then, 12(S)-HETE was determined by EIA. Experiments were performed in triplicate, error bars indicate mean \pm SEM and asterisks indicate significance $(p<0.05)$. b Inhibition of CYP1A1 activity in breast cancer cells by xanthohumol and

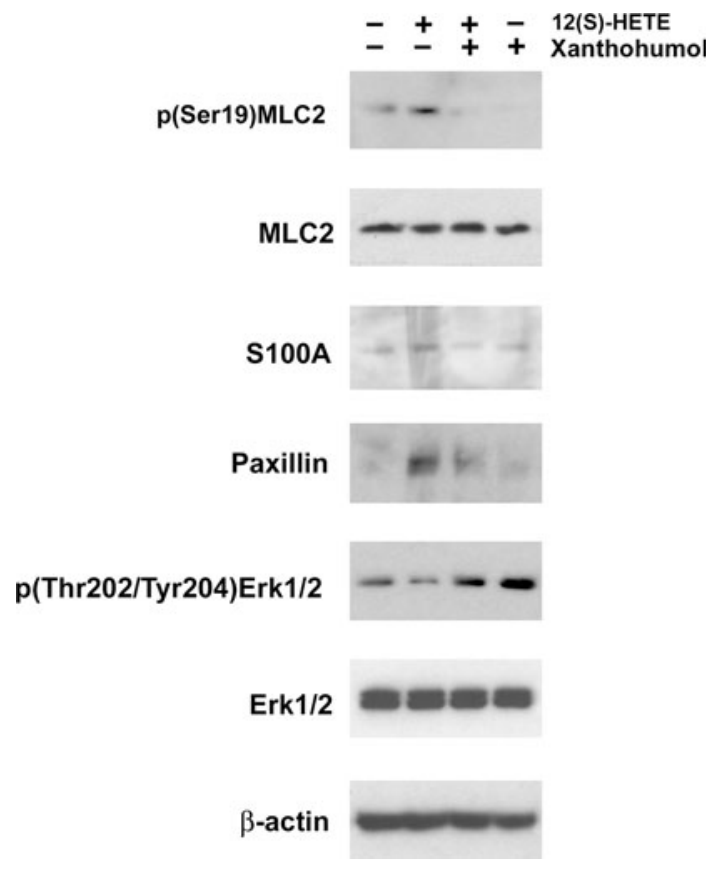

Fig. 5 Analysis of migratory and EMT markers in LECs upon treatment with xanthohumol. LECs were grown to confluence and then pretreated with $25 \mu \mathrm{M}$ xanthohumol or solvent (DMSO) for $30 \mathrm{~min}$; then, LECs were stimulated with $1 \mu \mathrm{M}$ 12(S)-HETE for $1 \mathrm{~h}$. Cells were lysed, proteins separated by SDS gel electrophoresis and subjected to Western blotting using the indicated antibodies. Staining with Ponceau $S$ and immunoblotting with anti- $\beta$-actin antibody controlled equal sample loading

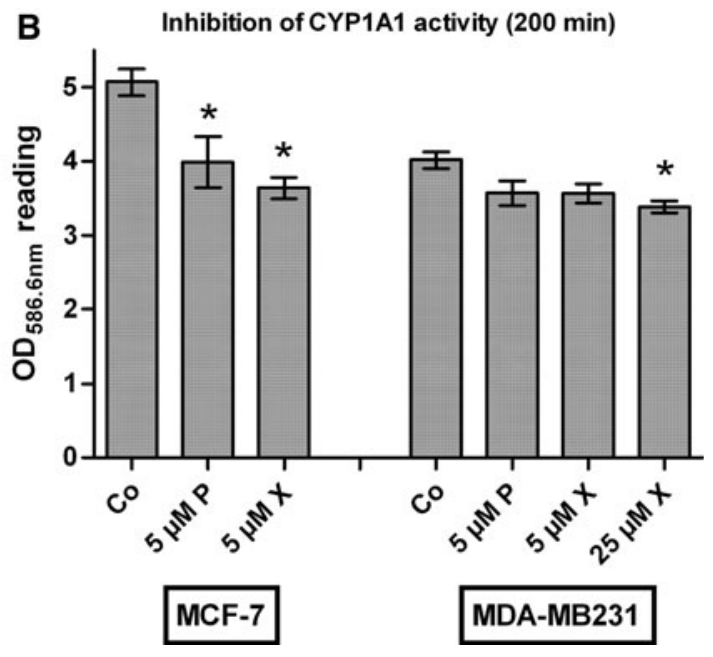

proadifen. MCF-7 and MDA-MB231 cells were kept under steroidfree conditions and treated with proadifen $(5 \mu \mathrm{M}$; P), or xanthohumol $(5,25 \mu \mathrm{M} ; \mathrm{X})$, or solvent (DMSO; Co). Then, $5 \mu \mathrm{M}$ ethoxyresorufin was added, and after $200 \mathrm{~min}$, the formation of resorufin was analysed, which is specific for CYP1A1 activity. Experiments were done in triplicate, error bars indicate mean \pm SEM and asterisks indicate significance $(p<0.05)$. No toxic effects were observed within the experimental setting

body (based on the in vitro data), the intake of xanthohumol-enriched beverages $(3.5 \mathrm{mg} / \mathrm{l})$ would exceed the respective body weight. Pure and encapsulated xanthohumol, however, could be sufficient to reach relevant concentrations. Though, studies on acute toxicity have to be performed first. The root of Sophora flavescens Ait. (traditional name: kushen), which contains isoxanthohumol and xanthohumol, is used in traditional Chinese medicine to treat viral hepatitis and cancer. In vivo, utilising Lewis lung cancer mouse model (C57BL/6 mice), sarcoma and hepatocellular carcinoma models kushen flavonoid preparations showed anti-cancer effects, and the maximum tolerated oral or intravenous doses were beyond $2.8 \mathrm{~g} / \mathrm{kg}$ and $750 \mathrm{mg} / \mathrm{kg}$, respectively (Sun et al. 2008; Sun et al. 2012). Also xanthohumol possesses antineoplastic activities in several cancer lines (Miranda et al. 1999; Pan et al. 2005). Xanthohumol was shown to repress both NF- $\mathrm{KB}$ and Akt pathways in endothelial cells and interfered with the angiogenic process, including inhibition of growth and of endothelial cell migration (Albini et al. 2006). This is in agreement with our data because the 12(S)-HETE-induced expression of paxillin (focal adhesion plaque phosphoprotein) was inhibited by xanthohumol. Paxillin controls rapid directional cell movement (Deakin and Turner 2008) and is associated in vivo and in vitro with enhanced endothelial cell motility and is necessary for cell-ECM contact (Huang et al. 2003; Zaidel-Bar et al. 2003). 
12(S)-HETE induced also other markers of cell mobility and EMT and therefore, of stemness and metastatic potential such as MLC2, MYPT1 and S100A4. Hence, drugs preventing or reversing EMT possess a property that is urgently needed as a therapeutic principle against metastatic outspread. Xanthohumol prevented the induction of S100A4, MLC2 and paxillin, while Bay11-7082 blocked only that of S100A4. This suggests that xanthohumol exhibits a wide spectrum of activities that may synergise in the inhibition of CCIDs, i.e., by inhibition of EMT markers. Beyond that, xanthohumol has been shown to possess antioxidant (Hartkorn et al. 2009) as well as radicalinducing properties (Strathmann et al. 2010). Radicals, however, are not involved in CCID formation (Madlener et al. 2010; Kerjaschki et al. 2011).

MCF-7 cells (in contrast to MDA-MB231 breast cancer cells) are oestrogen-receptor (ER) positive (Roomi et al. 2005) and previous studies have shown that xanthohumol blocks oestrogenic effects. The flavonoid binds to the ER and it was postulated that this property may prevent breast cancer (Gerhäuser et al. 2002). It is, however, unlikely that binding to oestrogen receptor was the reason why xanthohumol inhibited MCF-7-induced CCID formation, because some colon cancer spheroids induce gaps by the same mechanisms as MCF-7 cells (Kerjaschki et al. 2011), yet colon cancer cells do not express ER receptors.

Low concentrations of xanthohumol (IC50 $\sim 5 \mu \mathrm{M}$ ) reduced MCF-7 spheroid-triggered CCIDs and with increasing concentrations xanthohumol-pretreated spheroids gradually lost the contact to the underlaying LEC monolayer. This was consistent with an NF-kB-inhibitory activity (Viola et al. 2012) at higher xanthohumol concentrations (Fig. 6) and with the fact that high xanthohumol concentrations were required to inhibit MDA-MB231 spheroid-triggered CCIDs $\left(\mathrm{IC}_{50} \sim 100 \mu \mathrm{M}\right.$ ) as this breast cancer cell line induces CCIDs through the NF-kB pathway (Bay11-7082 inhibited MDA-MB231-triggered CCID formation with an $\mathrm{IC}_{50}$ of $\left.\sim 10 \mu \mathrm{M}\right)$. In contrast, at low xanthohumol concentrations $(5 \mu \mathrm{M})$, another CCID-forming mechanism was affected that was more active in MCF-7 than in MDA-MB231 cells. We propose that this mechanism involves the activity of CYP1A1 since CYPs may contribute to CCID formation (Kretschy et al. 2013). CYP1A1 plays a role in breast cancer metastasis (Jiang et al. 2007), and therefore, its function in CCID formation needs to be investigated in more detail. At a concentration of $5 \mu \mathrm{M}$, xanthohumol inhibited CYP1A1 but did not favour the production of 12(S)-HETE by ALOX12 (which competes for the same substrate). Interestingly, CYP is also involved in the metabolism of isoxanthohumol (Guo et al. 2006). Furthermore, it needs to be determined through which specific metabolites CYPs of MCF-7 cells signal to LECs thereby triggering LEC migration. Interestingly, the

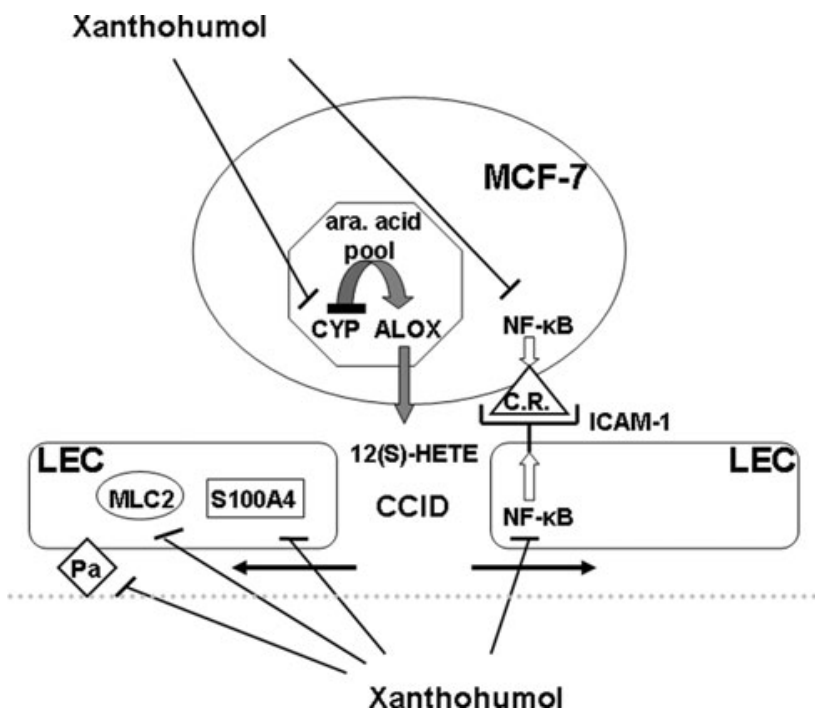

Fig. 6 The inhibitory mechanisms of xanthohumol on CCID formation. Xanthohumol affects CCID-forming mechanisms in LECs as well as in MCF-7 cells. In particular, xanthohumol inhibits the activity of NF- $\mathrm{KB}$ in LECs and hence also the expression of ICAM-1. Since molecular adhesion of MCF-7 cells to LECs is mandatory for CCIDs, the down-regulation of ICAM-1 by xanthohumol interferes with the formation of CCIDs. In addition, xanthohumol inhibits the mobility marker proteins S100A4, MLC2 and paxillin (Pa), which are required for cell movement during CCID formation. In MCF-7 cells, xanthohumol inhibits also NF- $\mathrm{\kappa B}$ and likely the counter-receptor of ICAM-1, LFA-1, which facilitates adhesion from the MCF-7-side. Xanthohumol inhibits also CYP1A1 (CYP) and, as a consequence, supplies ALOX12/15 (ALOX) with additional substrate (arachidonic acid; ara. acid) for which CYP and ALOX are competing. This leads to an increase in 12(S)-HETE synthesis (but only at concentrations of more than $5 \mu \mathrm{M}$ xanthohumol), which positively influences CCID formation. Nevertheless, the net effect of xanthohumol on CCID formation is negative, because the inhibition of NF- $\kappa \mathrm{B}$ and mobility proteins prevails. Interestingly, also proadifen, which is a specific inhibitor of CYPs, attenuates CCIDs despite induction of 12(S)-HETE production because it also down-regulates paxillin, MLC2, NF- $\mathrm{KB}$ and ICAM-1. The role of CYPs (and the mechanisms of proadifen) regarding the intravasation of tumour cells into the lymphatic vasculature has not been established yet. Hence, detailed future investigations on the function of CYPs (and proadifen) on CCID formation are required

transcription factor aryl hydrocarbon receptor 1 (Ahr-1), which targets CYP1A1 (Nannelli et al. 2009) and positively correlates with CYP1 expression in MCF-7 clones (Spink et al. 2012), was reported to regulate focal adhesion sites and cell migration of, i.e., human mammary epithelial cells (Tomkiewicz et al. 2012; Brooks and Eltom 2011), a noxus in which also paxillin is involved. Whether this mechanism is also true for endothelial cells needs to be investigated. Another target of Ahr, the transcription factor Nrf-2 (Nannelli et al. 2009), which detoxifies ROS by regulating SOD and catalase (Köhle and Bock 2007; Li et al. 2008), is unlikely to play a role in CCID formation because radicals were shown not to contribute to this process (Madlener et al. 2010). 


\section{Conclusion}

Here, we describe a new property of xanthohumol, which inhibits CCID formation in LEC monolayers underneath tumour spheroids at low micromolar concentrations. Specifically, xanthohumol targeted marker proteins typical for an EMT type of cell plasticity as it inhibited the expression of paxillin and S100A4 and the activity of MLC2, as well as the adhesion of tumour cells to endothelial cells, and the inhibition of CYP1A1 in breast cancer cells. Therefore, we provide evidence of a new anti-metastatic property of xanthohumol that could be exploited for the treatment of breast cancer.

Acknowledgments We wish to thank Toni Jäger for preparing the figures and to Prof. J. Ulrichova for kind gift of HUVEC cells. Further, Grant Nos. GACR (P505/11/1163) and ED0007/01/01 (both to M.S.) from the Centre of the Region Haná for Biotechnological and Agricultural Research, a grant of the Fellinger foundation (to G.K.), grants of the Herzfelder family foundation (to T.S., H.D., P.S. and M.G.), a grant of the "Hochschuljubilaeumsstiftung der Stadt Wien" grant number H-2498/2011 (to P.S.), a scholarship from the Austrian exchange service OeAD (to K.J.), and grants by the Austrian Science Fund, FWF, grant numbers P19598-B13 and P20905-B13 (to W.M.), S10704-B03 and S10704-B13 (to V.M.D.) and by the European Union, FP7 Health Research, project number HEALTH-F4-2008202047 (to W.M.) are gratefully acknowledged.

Conflict of interest None.

\section{References}

Albini A, Dell'Eva R, Vené R, Ferrari N, Buhler DR, Noonan DM, Fassina $G$ (2006) Mechanisms of the antiangiogenic activity by the hop flavonoid xanthohumol: NF-kappaB and Akt as targets. FASEB J 20(3):527-529

Brooks J, Eltom SE (2011) Malignant transformation of mammary epithelial cells by ectopic overexpression of the aryl hydrocarbon receptor. Curr Cancer Drug Targets 11(5):654-669

Colgate EC, Miranda CL, Stevens JF, Bray TM, Ho E (2007) Xanthohumol, a prenylflavonoid derived from hops induces apoptosis and inhibits NF-kappaB activation in prostate epithelial cells. Cancer Lett 246(1-2):201-209

Collins T, Read MA, Neish AS, Whitley MZ, Thanos D, Maniatis T (1995) Transcriptional regulation of endothelial cell adhesion molecules: NF-kappa B and cytokine-inducible enhancers. FASEB J 9(10):899-909

Deakin NO, Turner CE (2008) Paxillin comes of age. J Cell Sci 121(15):2435-2444

Gerhäuser C, Alt A, Heiss E, Gamal-Eldeen A, Klimo K, Knauft J, Neumann I, Scherf HR, Frank N, Bartsch H, Becker H (2002) Cancer chemopreventive activity of Xanthohumol, a natural product derived from hop. Mol Cancer Ther 1(11):959-969

Giessrigl B, Yazici G, Teichmann M, Kopf S, Ghassemi S, Atanasov AG, Dirsch VM, Grusch M, Jäger W, Ozmen A, Krupitza G (2012) Effects of scrophularia extracts on tumor cell proliferation. Death and intravasation through lymphendothelial cell barriers. Int J Oncol 40(6):2063-2074

Gridling M, Stark N, Madlener S, Lackner A, Popescu R, Benedek B, Diaz R, Tut FM, Nha Vo TP, Huber D, Gollinger M, Saiko P,
Ozmen A, Mosgoeller W, De Martin R, Eytner R, Wagner KH, Grusch M, Fritzer-Szekeres M, Szekeres T, Kopp B, Frisch R, Krupitza G (2009) In vitro anti-cancer activity of two ethnopharmacological healing plants from Guatemala Pluchea odorata and Phlebodium decumanum. Int J Oncol 34(4):1117-1128

Grusch M, Polgar D, Gfatter S, Leuhuber K, Huettenbrenner S, Leisser C, Fuhrmann G, Kassie F, Steinkellner H, Smid K, Peters GJ, Jayaram H, Klepal T, Szekeres T, Knasmüller S, Krupitza G (2002) Maintainance of ATP favours apoptosis over necrosis triggered by benzamide riboside. Cell Death Differ 9(2):169-178

Guo J, Nikolic D, Chadwick LR, Pauli GF, van Breemen RB (2006) Identification of human hepatic cytochrome P450 enzymes involved in the metabolism of 8-prenylnaringenin and isoxanthohumol from hops (Humulus lupulus L.). Drug Metab Dispos 34(7):1152-1159

Hartkorn A, Hoffmann F, Ajamieh H, Vogel S, Heilmann J, Gerbes AL, Vollmar AM, Zahler S (2009) Antioxidant effects of xanthohumol and functional impact on hepatic ischemia-reperfusion injury. J Nat Prod 72(10):1741-1747

Holden NS, Catley MC, Cambridge LM, Barnes PJ, Newton R (2004) ICAM-1 expression is highly NF-kappaB-dependent in A549 cells. No role for ERK and p38 MAPK. Eur J Biochem 271(4):785-791

Honn KV, Tang DG, Grossi I, Duniec ZM, Timar J, Renaud C, Leithauser M, Blair I, Johnson CR, Diglio CA, Kimler VA, Taylor JD, Marnett LJ (1994) Tumour cell-derived 12(S)hydroxyeicosatetraenoic acid induces microvascular endothelial cell retraction. Cancer Res 54(2):565-574

Huang C, Rajfur Z, Borchers C, Schaller MD, Jacobson K (2003) JNK phosphorylates paxillin and regulates cell migration. Nature 424(6945):219-223

Jiang JG, Ning YG, Chen C, Ma D, Liu ZJ, Yang S, Zhou J, Xiao X, Zhang XA, Edin ML, Card JW, Wang J, Zeldin DC, Wang DW (2007) Cytochrome p450 epoxygenase promotes human cancer metastasis. Cancer Res 67(14):6665-6674

Kerjaschki D, Bago-Horvath Z, Rudas M, Sexl V, Schneckenleithner C, Wolbank S, Bartel G, Krieger S, Kalt R, Hantusch B, Keller T, Nagy-Bojarszky K, Huttary N, Raab I, Lackner K, Krautgasser K, Schachner H, Kaserer K, Rezar S, Madlener S, Vonach C, Davidovits A, Nosaka H, Hämmerle M, Viola K, Dolznig H, Schreiber M, Nader A, Mikulits W, Gnant M, Hirakawa S, Detmar M, Alitalo K, Nijman S, Offner F, Maier TJ, Steinhilber D, Krupitza G (2011) Lipoxygenase mediates invasion of intrametastatic lymphatic vessels and propagates lymph node metastasis of human mammary carcinoma xenografts in mouse. J Clin Invest 121(5):2000-2012

Köhle C, Bock KW (2007) Coordinate regulation of Phase I and II xenobiotic metabolisms by the Ah receptor and Nrf2. Biochem Pharmacol 73(12): 1853-1862

Kozak W, Mayfield PM, Kozak A, Kluger MJ (2000) Proadifen (SKF-525A), an inhibitor of cytochrome P450, augments LPSinduced fever and exacerbates prostaglandin-E2 levels in rats. J Therm Biol 25(1):45-50

Kretschy N, Teichmann M, Kopf S, Atanasov AG, Saiko P, Vonach C, Viola K, Giessrigl B, Huttary N, Raab I, Krieger S, Jäger W, Szekeres T, Nijman SM, Mikulits W, Dirsch VM, Dolznig H, Grusch M, Krupitza G (2013) In vitro inhibition of breast cancer spheroid-induced lymphendothelial defects resembling intravasation into the lymphatic vasculature by acetohexamide, isoxsuprine, nifedipin and proadifen. Br J Cancer 108(3):570-578

Li W, Khor TO, Xu C, Shen G, Jeong WS, Yu S, Kong AN (2008) Activation of Nrf2-antioxidant signaling attenuates NFkappaBinflammatory response and elicits apoptosis. Biochem Pharmacol 76(11):1485-1489

Madlener S, Svacinová J, Kitner M, Kopecky J, Eytner R, Lackner A, Vo TP, Frisch R, Grusch M, De Martin R, Dolezal K, Strnad M, 
Krupitza G (2009) In vitro anti-inflammatory and anticancer activities of extracts of Acalypha alopecuroidea (Euphorbiaceae). Int J Oncol 35(4):881-891

Madlener S, Saiko P, Vonach C, Viola K, Huttary N, Stark N, Popescu R, Gridling M, Vo NT, Herbacek I, Davidovits A, Giessrigl B, Venkateswarlu S, Geleff S, Jäger W, Grusch M, Kerjaschki D, Mikulits W, Golakoti T, Fritzer-Szekeres M, Szekeres T, Krupitza G (2010) Multifactorial anticancer effects of digalloyl-resveratrol encompass apoptosis, cell-cycle arrest, and inhibition of lymphendothelial gap formation in vitro. $\mathrm{Br} \mathrm{J}$ Cancer 102(9):1361-1370

Magalhães PJ, Carvalho DO, Cruz JM, Guido LF, Barros AA (2009) Fundamentals and health benefits of xanthohumol, a natural product derived from hops and beer. Nat Prod Commun 4(5):591-610

Miranda CL, Stevens JF, Helmrich A, Henderson MC, Rodriguez RJ, Yang YH, Deinzer ML, Barnes DW, Buhler DR (1999) Antiproliferative and cytotoxic effects of prenylated flavonoids from hops (Humulus lupulus) in human cancer cell lines. Food Chem Toxicol 37(4):271-285

Nannelli A, Rossignolo F, Tolando R, Rossato P, Longo V, Gervasi PG (2009) Effect of beta-naphthoflavone on AhR-regulated genes (CYP1A1, 1A2, 1B1, 2S1, Nrf2, and GST) and antioxidant enzymes in various brain regions of pig. Toxicology 265(3): 69-79

Pan L, Becker H, Gerhäuser C (2005) Xanthohumol induces apoptosis in cultured 40-16 human colon cancer cells by activation of the death receptor- and mitochondrial pathway. Mol Nutr Food Res 49(9):837-843

Roomi MW, Ivanov V, Kalinovsky T, Niedzwiecki A, Rath M (2005) In vitro and in vivo antitumorigenic activity of a mixture of lysine, proline, ascorbic acid, and green tea extract on human breast cancer lines MDA-MB-231 and MCF-7. Med Oncol 22 (2): $129-138$

Spink BC, Bennett JA, Lostritto N, Cole JR, Spink DC (2012) Expression of the aryl hydrocarbon receptor is not required for the proliferation, migration, invasion, or estrogen-dependent tumorigenesis of MCF-7 breast cancer cells. Mol Carcinog. doi: 10.1002/mc.21889. (Epub ahead of print)

Stevens JF, Page JE (2004) Xanthohumol and related prenylflavonoids from hops and beer: to your good health! Phytochemistry 65(10): 1317-1330

Stevens JF, Taylor AW, Deinzer ML (1999) Quantitative analysis of xanthohumol and related prenylflavonoids in hops and beer by liquid chromatography-tandem mass spectrometry. J Chromatogr A 832(1-2):97-107
Strathmann J, Klimo K, Sauer SW, Okun JG, Prehn JH, Gerhäuser C (2010) Xanthohumol-induced transient superoxide anion radical formation triggers cancer cells into apoptosis via a mitochondriamediated mechanism. FASEB J 24(8):2938-2950

Sun MY, Zuo J, Duan JF, Han J, Fan SM, Zhang W, Zhu LF, Yao MH (2008) Antitumor activities of kushen flavonoids in vivo and in vitro. Zhong Xi Yi Jie He Xue Bao 6(1):51-59

Sun M, Cao H, Sun L, Dong S, Bian Y, Han J, Zhang L, Ren S, Hu Y, Liu C, Xu L, Liu P (2012) Antitumor activities of kushen: literature review. Evid Based Complement Alternat Med 2012:373219. doi:10.1155/2012/373219. Epub 2012 Aug 28. PMID:22969826

Tomkiewicz C, Herry L, Bui LC, Métayer C, Bourdeloux M, Barouki R, Coumoul X (2012) The aryl hydrocarbon receptor regulates focal adhesion sites through a non-genomic FAK/Src pathway. Oncogene. doi:10.1038/onc.2012.197. (Epub ahead of print)

Uchide K, Sakon M, Ariyoshi H, Nakamori S, Tokunaga M, Monden M (2007) Cancer cells cause vascular endothelial cell retraction via 12(S)-HETE secretion; the possible role of cancer cell derived microparticle. Ann Surg Oncol 14(2):862-868

Viola K, Kopf S, Huttary N, Vonach C, Kretschy N, Teichmann M, Giessrigl B, Raab I, Stary S, Krieger S, Keller T, Bauer S, Hantusch B, Szekeres T, de Martin R, Jäger W, Mikulits W, Dolznig H, Krupitza G, Grusch M (2012) Bay11-7082 inhibits the disintegration of the lymphendothelial barrier triggered by MCF-7 breast cancer spheroids; the role of ICAM-1 and adhesion. Br J Cancer 108(3):564-569

Vonach C, Viola K, Giessrigl B, Raab I, Huttary N, Kalt R, Krieger S, Vo NTP, Madlener S, Bauer S, Marian B, Hämmerle M, Kretschy N, Teichmann M, Hantusch B, Stary S, Unger C, Seelinger M, Eger A, Mader R, Jäger W, Schmidt W, Grusch M, Dolznig H, Mikulits W, Krupitza G (2011) NF-кB mediates the12(S)-HETE-induced endothelial to mesenchymal transition of lymphendothelial cells during the intravasation of breast carcinoma cells. Br J Cancer 105(2):263-271

Wunderlich S, Zürcher A, Back W (2005) Enrichment of xanthohumol in the brewing process. Mol Nutr Food Res 49(9):874-881

Zaidel-Bar R, Ballestrem C, Kam Z, Geiger B (2003) Early molecular events in the assembly of matrix adhesions at the leading edge of migrating cells. J Cell Sci 116(22):4605-4613

Zhang JS, Nelson M, Wang L, Liu W, Qian CP, Shridhar V, Urrutia $\mathrm{R}$, Smith DI (1998) Identification and chromosomal localization of CTNNAL1, a novel protein homologous to alpha-catenin. Genomics 54(1):149-154 